\title{
Subglacial environment inferred from bedrock-coating siltskins, Mendenhall Glacier, Alaska, U.S.A.
}

\author{
Carissa L. Carter, ${ }^{1}$ David P. Dethier, ${ }^{1}$ Robert L. NEWTON ${ }^{2}$ \\ ${ }^{1}$ Department of Geosciences, Williams College, Williamstown, Massachusetts 01267, U.S.A. \\ E-mail:ccarter@es.ucsc.edu \\ ${ }^{2}$ Department of Geology, Smith College, Northampton, Massachusetts 01063, U.S.A.
}

\begin{abstract}
Retreat of Mendenhall Glacier nearJuneau, Alaska, U.S.A., has exposed a bedrock ridge spotted with "siltskins", patchy coatings of calcite-cemented clay-to sandsized lithic grains. Coatings $0.5-20 \mathrm{~mm}$ thick occur in two distinct morphologies. Thin, striated siltskins coat mainly stoss faces. Thicker, corrugated siltskins on lee faces consist of parallel micro-ridges elongated downslope. Thin-section analysis shows that siltskins consist of a basal, calcite-rich layer overlain by microlaminated layers of calcite-cemented lithic grains. Scanning electron microscope (SEM) energy-dispersive spectrometer (EDS) analysis of laminae and surfaces shows laterally persistent $\mathrm{Ca} / \mathrm{Si}$ differences. Isotopic values for $\delta \mathrm{O}^{18}$ and $\delta \mathrm{O}^{13}$ ranged from $-19.52 \%$ to $-12.74 \%$ and $-6.18 \%$ to $-3.44 \%$, respectively, consistent with deposition from subglacial waters of varying isotopic composition and with derivation of carbon from inorganic sources. Corrugated siltskins are complex depositional features modified by erosional processes. Parallel micro-ridges spaced 1$10 \mathrm{~mm}$ apparently formed as sediment-rich water dripped down lee-slope rock faces. Icerock separation, flow energy and the transported sediment controlled the layering and depositional forms. Siltskins probably formed when a subglacial cavity system was active on the rock ridge and provide clues about how microscale hydrologic processes interact with larger-scale subglacial systems.
\end{abstract}

\section{INTRODUCTION}

The landscape revealed by retreating glaciers provides evidence, much of it ephemeral, for subglacial processes that are difficult to observe directly. Glaciers that thin over rough bedrock surfaces continue to slide by regelation as adjacent subsurface cavity systems develop and enlarge. Subglacial deposits, including the cemented coatings we describe here, provide insight into subglacial conditions.

Rock-coating, carbonate-cemented lithic deposits (siltskins) that we describe from Mendenhall Glacier, Alaska, U.S.A., record processes that were active under ice that has been thinning and retreating since the Little Ice Age. Such processes may be relatively common near the margins of the thousands of glaciers that are retreating worldwide as climate continues to warm. Subglacial deposits provide important clues about how glaciers are affected by and record changing climate and how they have contributed to global climate change throughout Earth history (Paterson, 1994).

\section{Basal sliding and subglacial precipitates}

Subglacial precipitates and other geomorphic features exposed on former glacier beds provide suggestive evidence for regelation-related processes at the ice-bedrock interface (Ford and others, 1970; Hallet 1975, 1976a, b, 1979; Hallet and Anderson, 1980; Sharp and others, 1990; Dixon and others, 2002).

Regelation and enhanced plastic flow cause pressuremelting of temperate ice on stoss (upflow) sides of bedrock bumps and flow of a microns-thick regelation film in the lee of obstacles (Weertman, 1957; Paterson, 1994). Formation of thin layers of calcite and silica from regelation and other exclusion processes affects thermal and hydrologic properties near the ice-rock interface (Hallet, 1976).

Subglacial carbonate coatings broadly similar to Mendenhall Glacier "siltskins" have been described from proglacial environments in Alberta, Canada, and the northern United States (Ford and others, 1970; Hallet, 1976a; Hallet and Anderson, 1980), near Mount Rainier, Washington, U.S.A. (Hallet, 1975), at Glacier de Tsanfleuron, Switzerland (Sharp and others, 1990), and from an alpine environment in Karkevagge, Sweden (Dixon and others, 2002).

Exclusion of solutes during subglacial freezing likely enriches subglacial meltwater in solutes and leads locally to the formation of cemented coatings. Hallet (1979) reasoned that lithic fragments incorporated into carbonate coatings must have traveled through the basal water film, and therefore the size distribution of these particles should reflect the thickness of the regelation layer. Sharp and others (1990) suggest that specific properties of the coatings depend on the degree of basal freezing when they formed. Open vs closed drainage systems and the thickness of the water film both contribute to the degree of saturation of calcite in the basal ice and the abundance of impurities trapped in the calcite during precipitation.

Bedrock exposed at Mendenhall Glacier is carbonatepoor, and siltskins consist mainly of lithic grains cemented with calcite. Siltskin micromorphology and lack of carbonate in local substrate suggests that subglacial processes 
beneath Mendenhall Glacier are similar to those studied by Hallet (1976a, b) and by Sharp and others (1990), but the ratio of precipitated calcite to embedded lithic fragments in siltskins is considerably lower than in previously studied coatings. Precipitation of siltskins at Mendenhall Glacier provides clues about subglacial chemical and hydrologic conditions under thinning, temperate glaciers.

\section{SETTING}

\section{Location, glacier characteristics and physiography}

Mendenhall Glacier flows south-southwest from the southern Juneau Icefield in the rugged Coast Mountains of southeastern Alaska, terminating in Mendenhall Lake (Fig. la). Near Juneau, summit elevations range from about 1500 to $3000 \mathrm{~m}$ (Wahrhaftig, 1992). Mendenhall Glacier is about $19 \mathrm{~km}$ long, averages $2.4 \mathrm{~km}$ wide and has been retreating since AD 1750 at a modern rate of about $27 \mathrm{ma}^{-1}$ (http:// www.crevassezone.org). During retreat, the glacier deposited a sequence of moraines and began to expose Mendenhall Lake, the current depositional sink for the glacier, about AD 1930.

About 1950, the retreating ice front exposed a $140 \mathrm{~m}$ high bedrock ridge developed on pervasively jointed, steeply dipping metasedimentary rocks. The west/southwest side of the ridge is steep and tapers east/northeast toward the glacier snout. Southeast-trending troughs cut the eastern slope of the rock ridge and likely channelized subglacial water flow as the ice thinned. Decimeter-scale bumps are ubiquitous on the east/northeast slope of the ridge. In this study we define stoss slopes as the up-glacier oriented faces of these bumps. P-forms and striae (Menzies, 1995) are common on most of the bedrock ridge. Till and other coarse glacial deposits are preserved only locally.

\section{METHODS}

\section{Field}

We mapped the distribution of siltskins on the bedrock ridge and collected rock, ice and water samples, using global positioning system (GPS) control. GPS measurements were also used to map the July 2000 ice front, local topography, areas with unusually high siltskin cover, as well as a "zero line" which marked the outer limit of preserved siltskins. We used these measurements to construct a topographic map of the newly exposed area in front of Mendenhall Glacier. We ran transects (8-12 measurement points) normal to the ice front over the Mendenhall rock ridge to provide a spatial context for our observations. At each point we measured local slope and striation direction and estimated the maximum percentage cover for siltskins using a $1 \mathrm{~m}$ square placed on the most heavily coated rock face. We measured per cent cover only on stoss faces. Lee face cover, higher and thicker than stoss cover on most bumps, varied proportionally to stoss values. We noted orientation, striation and local slope direction for all siltskin samples. Our sampling and analysis focused on "corrugated" siltskins common on lee slopes, but we also sampled the thinner, striated siltskins typical of stoss slopes.

We collected clean ice from the center of the ice front and basal ice at two locations: the ice front on the western side of the glacier, and the ice front near the eastern extent of the rock ridge (Fig. la). C. L. Carter collected a subglacial water
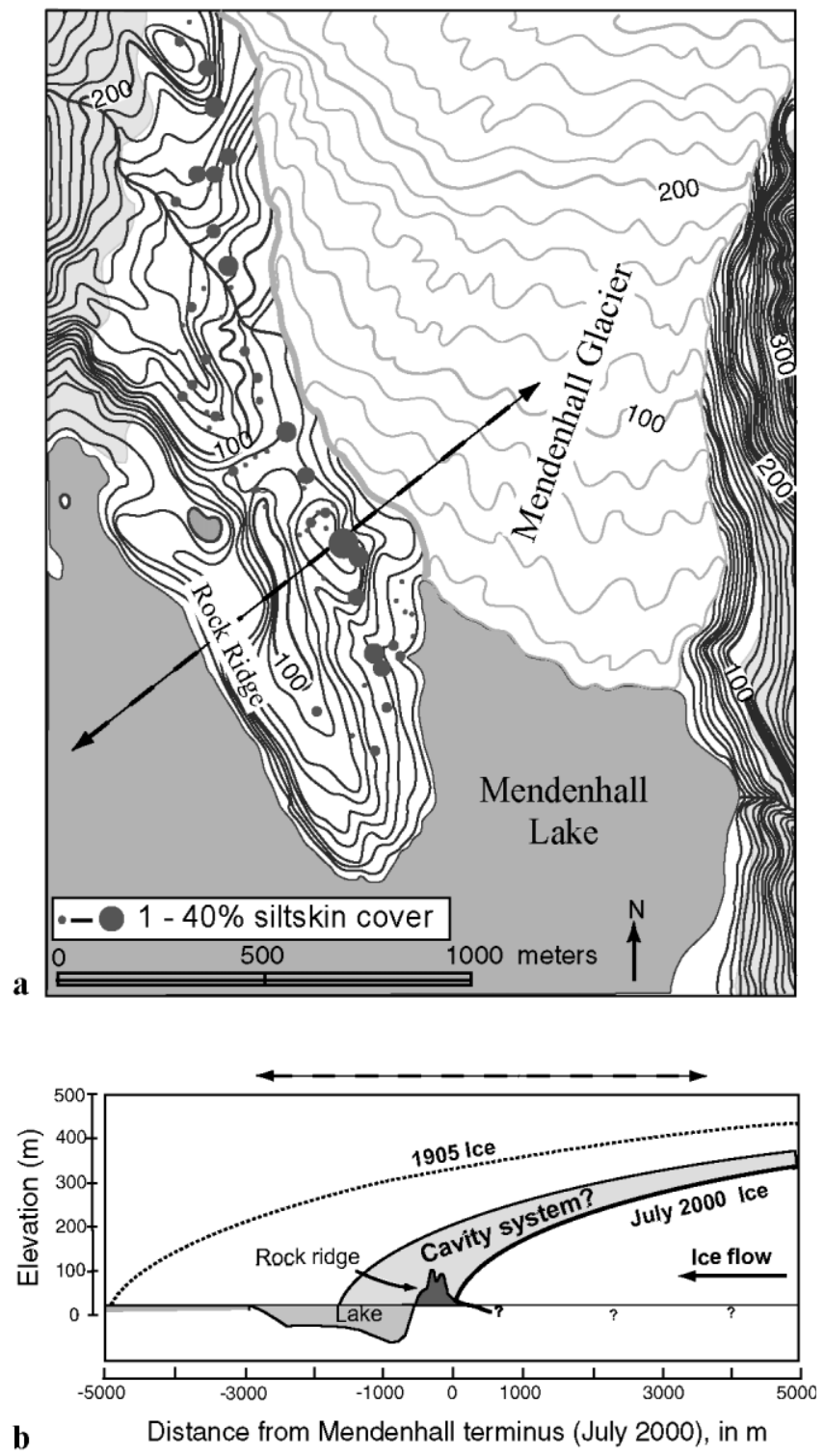

Fig. 1. (a) Topographic map of the Mendenhall Glacier terminus (July 2000), adjacent rock ridge and Mendenhall Lake. Circles on rock ridge show sampling sites and local maximum percent of bedrock surfaces covered by siltskins. Dashed line indicates approximate transect location shown below. (b) Cross-section showing 1905 and July 2000 ice positions from ice-thickness profiles and distances determined by Miller (1975). Gray area indicates ice location when a subglacial cavity system likely was active on the rock ridge.

sample by crawling under the ice on the western side of the glacier. All samples were transported out of the field for filtration within 24 hours and for measurement of $\mathrm{pH}$, alkalinity and other parameters.

\section{Laboratory}

\section{Thin-section analysis}

We selected and analyzed thin sections from 17 epoxy-impregnated, oriented siltskin samples. Sections were cut parallel and normal to the microridges (corrugated samples) or striations. We classified internal structures in siltskins: basal and upper layering, cross-lamination, micro-laminations, wavy laminations, truncations and convoluted forms. Grain-size distribution was determined by point-counting 700 randomly selected grains on three samples. 

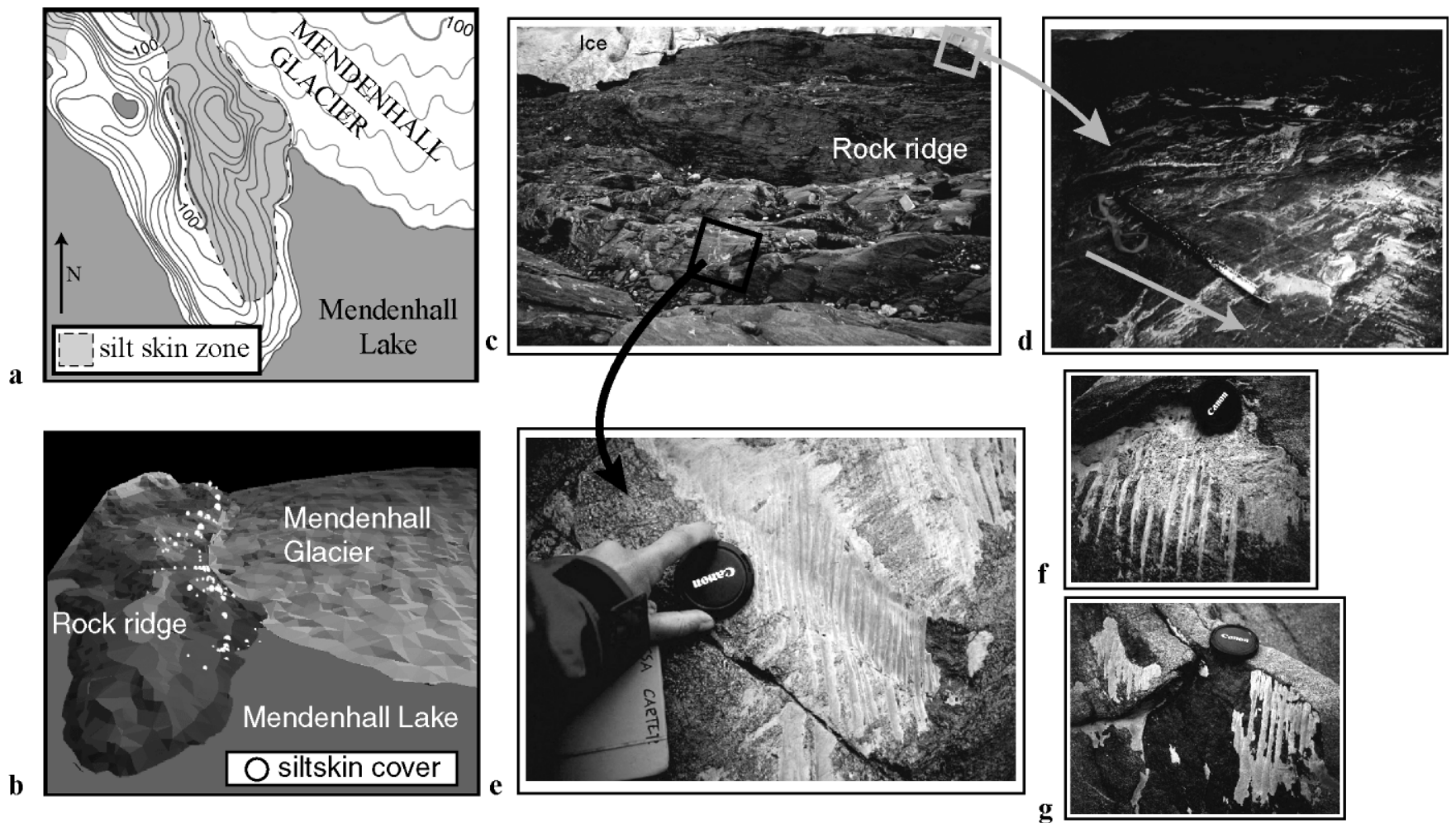

Fig. 2. Siltskin distribution and morphology in the vicinity of Mendenhall Glacier. (a) Topographic view. (b) Three-dimensional perspective showing maximum siltskin cover on the bedrock ridge west of Mendenhall Glacier. (c) Representative area of bedrock ridge and ice margin. (d) Striated siltskins under the ice margin. (e) Unweathered corrugated siltskins with microridges elongated downslope. $(f)$ Weathered corrugated siltskin cover. $(g)$ Corrugated siltskins flaking off a joint face on a lee slope.

\section{Sample chemistry}

We mounted selected siltskin samples and coated them with either Au-Pd or C for analysis with a Cambridge Stereoscan 100 scanning electron microscope (SEM) and Princeton Gamma Tech (PGT) electron dispersive spectrometer (EDS) using a Tracor Si-Li crystal detector with a beryllium window. We analyzed siltskin surfaces and cross-sections as well as sediment filtered from water and ice samples. We sampled an area of about $80 \mu \mathrm{m}^{2}$ for each EDS analysis and measured at intervals of $80-200 \mu \mathrm{m}$ on analytical transects of cross-sections.

We determined $\mathrm{pH}$ and acid-neutralizing capacity (ANC; end-point pH 4.5 for melted ice and water) using air-equilibrated samples in the laboratory. Filtered samples ( $0.45 \mu \mathrm{m}$ membrane filter) were analyzed by atomic absorp-

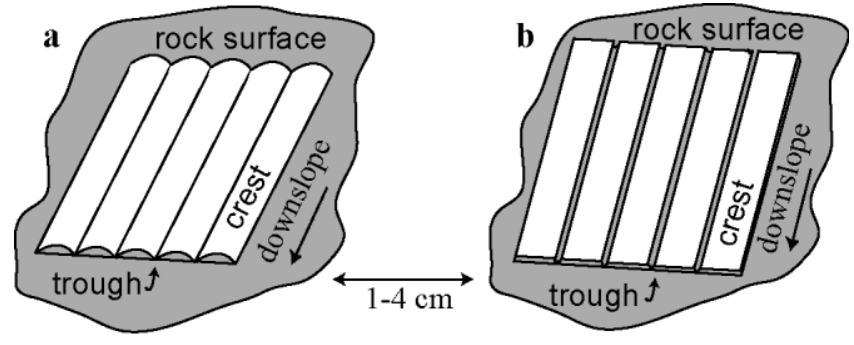

Fig. 3. Sketch showing varieties of corrugated siltskins. Both have crests and troughs, but (a) resembles half-cylinders placed side to side, and (b) has flatter-topped crests with troughs that appear to be carved by a pinpoint. Both (a) and (b) show micro-ridge elongation in the local downslope direction. tion using a Perkin-Elmer Analyst 300 (cations), and a Dionex IC 550 ion chromatograph (anions).

We measured carbon and oxygen isotopes on $10 \mathrm{~g}$ samples from each of five siltskins by Mountain Mass Spectrometry (Evergreen, Colorado). We prepared samples by scraping organic matter from the sample surface, and then crushing the siltskins with a mortar and pestle. Cement in powdered samples was reacted with $100 \%$ phosphoric acid using a MultiPrep system. The MultiPrep system uses a robotic sampler to access individual reaction vials held in a temperature-controlled rack. At $90^{\circ} \mathrm{C}$, the $\mathrm{CO}_{2}$ evolved was cryogenically concentrated in a small volume just outside the inlet system of a VG Micromass Sira mass spectrometer. The trapped $\mathrm{CO}_{2}$ was then transferred into the dual inlet system and analyzed. We report $\delta \mathrm{O}^{13}$ and $\delta \mathrm{O}^{18}$ with respect to Pee Dee Belemnite (PDB).

\section{DATA}

\section{Distribution of siltskins}

Siltskins are abundant in patches within $300 \mathrm{~m}$ of Mendenhall Glacier on the northeast-facing bedrock slope uncovered over the past 20 years (Fig. la). Cover generally decreases from the ice front to the top of the ridge, and no siltskins are preserved beyond the ridge crest. Siltskins are localized on certain parts of the ridge. Cover ranges from $0 \%$ on some of the steepest slopes and near the ridge crest, to $40 \%$ in local topographic lows closer to the ice front (Fig. 2). Siltskins are thickest and most abundant in the lee of decimeter-scale rock bumps and on joint surfaces oriented away from the direction of ice flow. Additionally, local stoss 


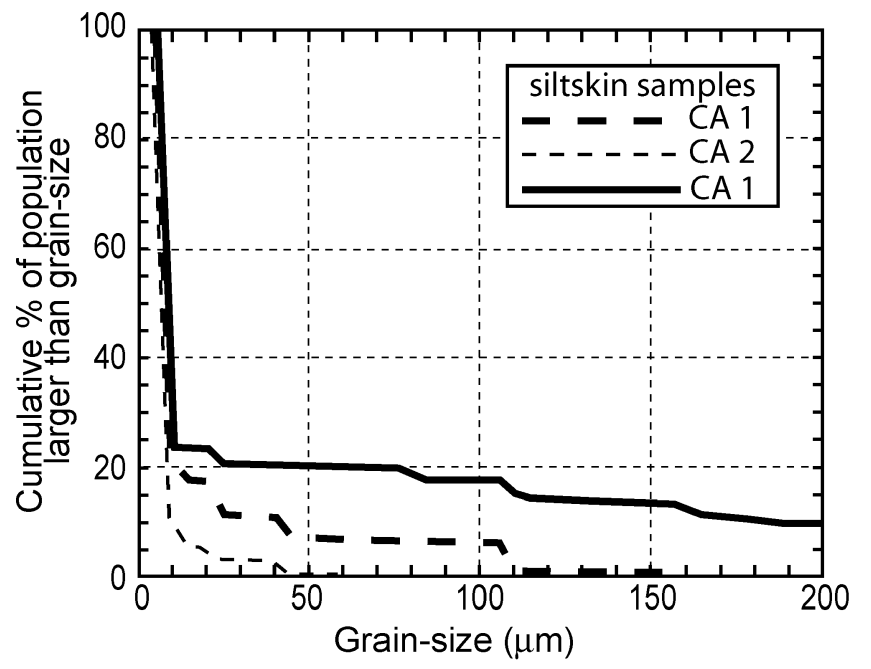

Fig. 4. Cumulative frequency plot of grain-size for three siltskin samples, determined by point-counting 700 randomly selected grains on each sample.

surfaces also preserve siltskins. The skins on these surfaces are compositionally similar to those on lee slopes, but are thinner and cover less surface area.

Siltskins are less abundant and progressively more weathered with increasing distance from the ice front. In cavities under the ice front, we observed wet siltskins on rock surfaces, and were able to scrape them with a knife. Away from the ice front, siltskins generally are hard and cemented to the bedrock but at many sites can be pried off with a pocket knife (Fig. 2). In other areas, siltskins are flaking off the rock in solid pieces. Skins are not preserved in areas where surface water flows frequently. Near the crest of the ridge, deglaciated in the mid- to late 1950s and some $250 \mathrm{~m}$ from the 2000 ice front, skins are sparse and locally have been colonized by small lichens or moss.

\section{Siltskin morphology and micromorphology}

Field mapping and thin-section analysis shows that siltskins near Mendenhall Glacier can be classified as striated or corrugated and that the thicker, more abundant corrugated forms preserve abundant microstructures. Siltskins are present on both stoss and lee sides of bedrock bumps, but morphology differs in these environments. Stoss sides preserve thin $(\sim 0.5-2.0 \mathrm{~mm})$, smoothed coatings that overlie striated bedrock and are striated in the direction of local ice flow; lee slopes preserve corrugated skins. Corrugated skins are thicker $(2-20 \mathrm{~mm})$ and consist of parallel microridges and troughs elongated in the local downslope direction (Figs 2 and 3). They coat rock surfaces that strike approximately normal to local ice-flow direction. Downslope direction is the major control on the direction of corrugations; orientation changes with slight bends in the rock surface. We generally observed both striated and corrugated siltskins, on rock faces at slopes of about $10-45^{\circ}$. However, in one locality, skins are cemented to the roof of an overhung rock face, and at some sites on lee slopes skins are cemented to vertical joint faces. We searched for but did not observe siltskins that filled cracks in rock surfaces or bedrock crevices. Although siltskins locally coat the few quartz and dolomite veins, these veins do not localize skin deposition or preservation.

The surface micromorphology of corrugated siltskins
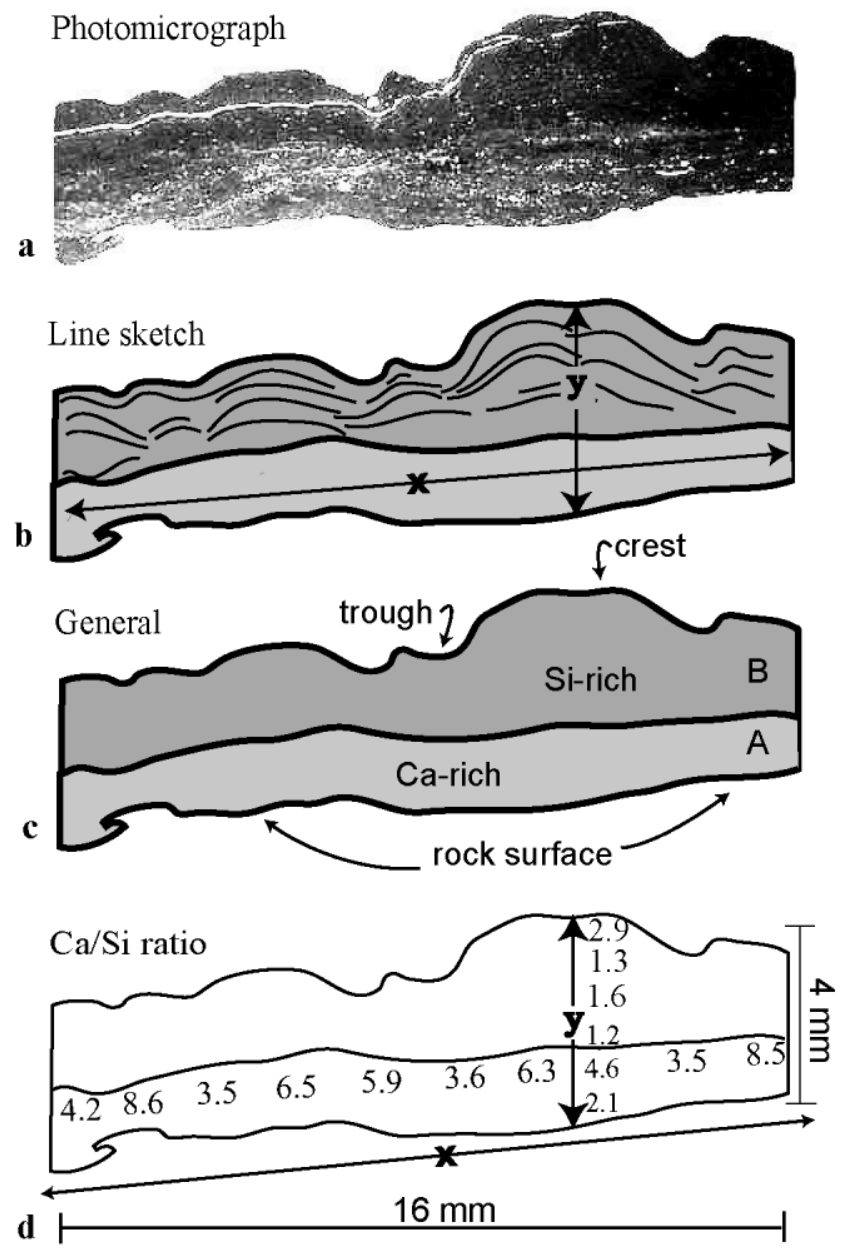

Fig. 5. (a) Photomicrograph of reflected light on thin section. (b) Line sketch showing basal calcite-rich massive layer and upper, microlaminated, silica-rich layer. (c) Line sketch showing lamination of siltskins into an unstructured calciterich layer ( $A$ ) and a microlaminated silica-rich layer (B). (d) Ca/Si ratios from EDS analyses plotted on sample.

varies considerably. Corrugations are composed of crests (micro-ridges) and microtroughs, the area between successive crests (Fig. 3). Some siltskins consist of a series of ridges that resemble half-cylinders lined up side to side, whereas other samples display flat-topped crests and grooved troughs that appear carved by a needle. Microridge wavelength ranges from 1 to $10 \mathrm{~mm}$ and is fairly consistent on a decimeter scale. Wavelength does not appear to be correlated with distance from the ice front, or position on the rock ridge, but longer wavelengths are loosely associated with thicker skins. Samples with the longest wavelengths are typical of local topographic lows on the rock ridge.

Thin-section analyses demonstrate that corrugated siltskins generally are fine-grained, have complex and varied internal structures, and display consistent variations in chemical composition. Individual layers are mainly well sorted and rich in clay and fine silt. Point-counting shows that $<10 \%$ of the grains in siltskins are sand-size; the mean value for three samples was approximately $21 \mu \mathrm{m}$ (Fig. 4). All of the corrugated siltskins we analyzed display two or more distinct zones, including a more massive, light-colored basal layer in contact with rock, and a darker, upper, microlaminated layer. The basal layer is calcite-rich, whereas upper layers are also calcite-cemented, but richer in silica (Fig. 5c). 
a

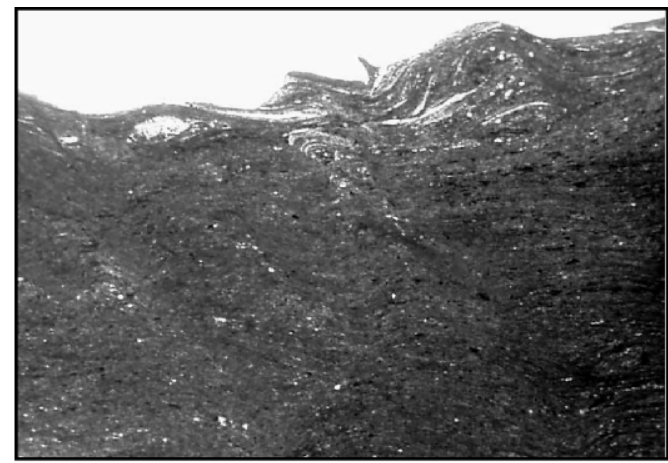

b

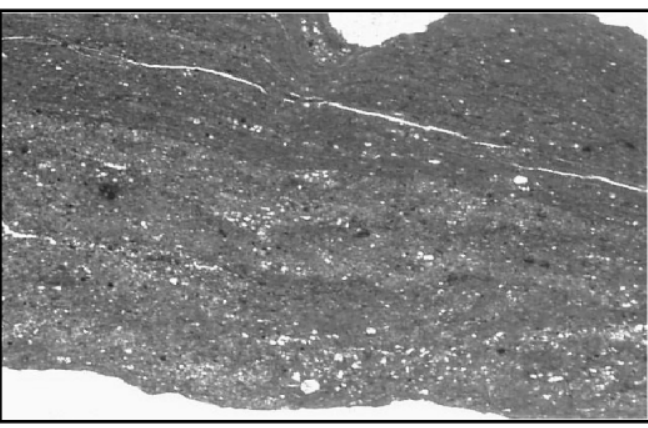

c

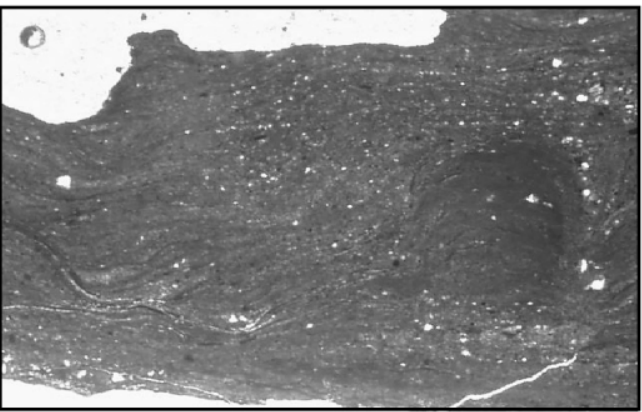

d

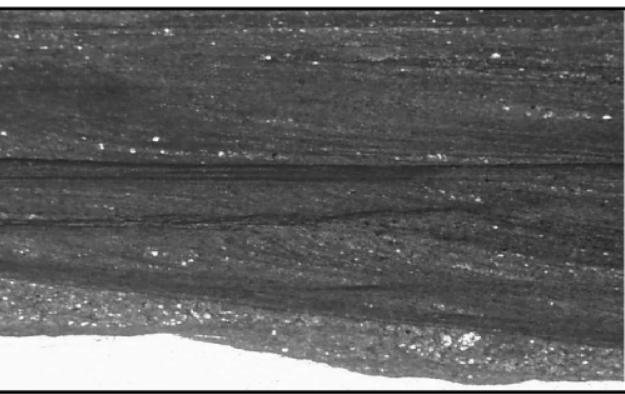

e

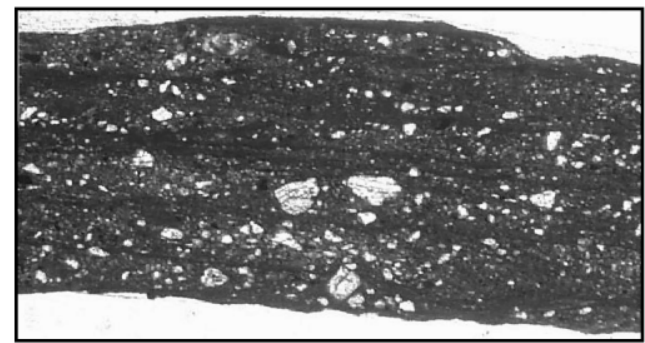

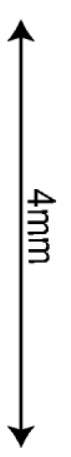

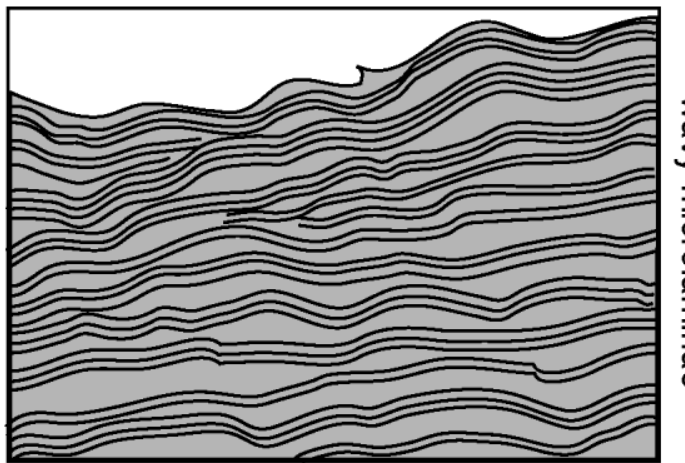

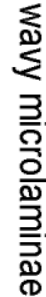
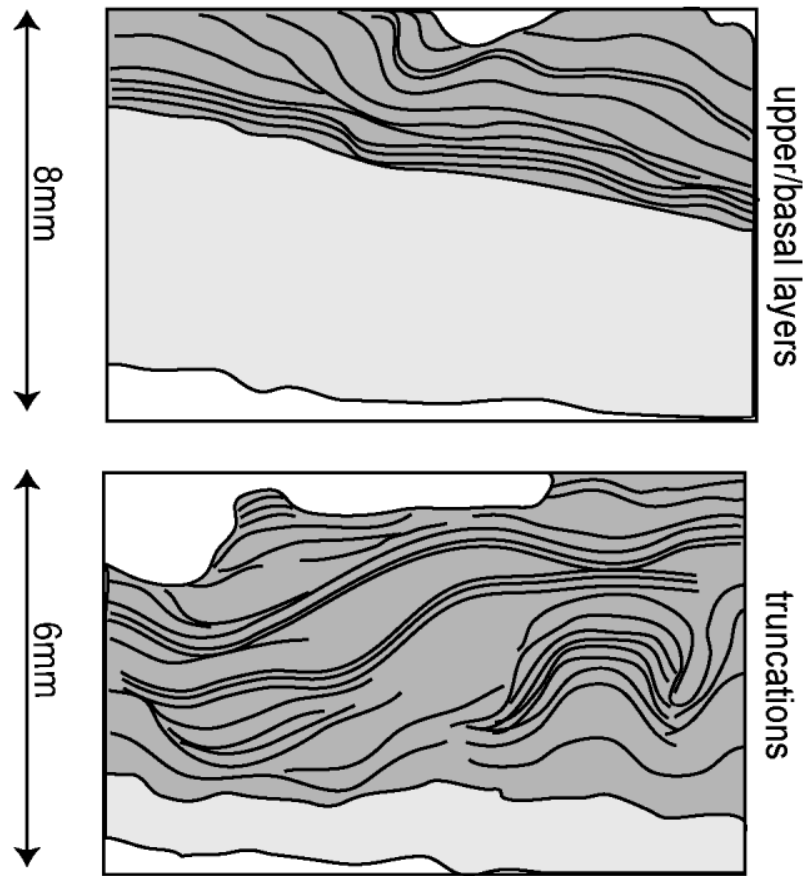

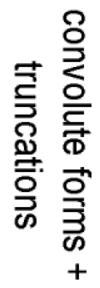
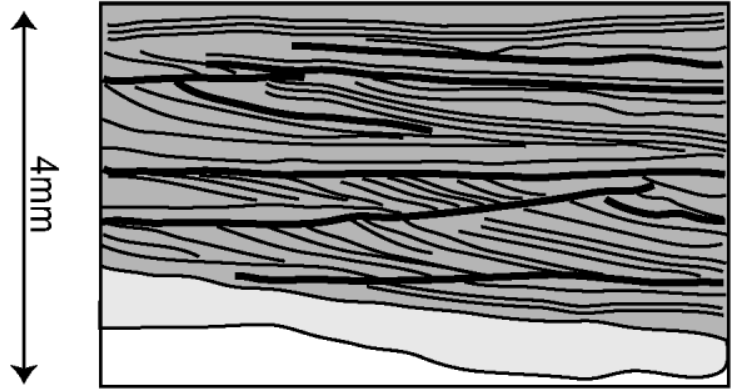

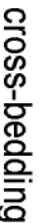

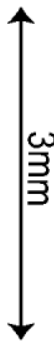

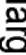 (1)

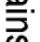
윽

Fig. 6. Photomicrographs of reflected light on thin sections, and corresponding line drawings depicting siltskin internal structures. (a) Wavy laminae; (b) distinct upper microlaminated layer and basal massive layer; (c) convolute forms and truncations; (d) cross-bedding; and (e) layering pockets with larger grains.

Microlaminae preserved in upper zones of siltskins display varied sedimentary and structural features: cross-laminae, wavy laminae, truncations and convoluted forms (Fig. 6). Microlaminae appear dark and light in transmitted light; individual laminae range in thickness from 1 to $20 \mu \mathrm{m}$. Mi- crostructures in siltskins display at least some directional control. Wavy laminae, truncations and convoluted forms are most common in transverse sections and are visible in diagonal sections. Cross-laminae are present in longitudinal sections as well as in transverse sections (Fig. 6). In some 
Table 1. EDS analyses of siltskin chemical composition

\begin{tabular}{|c|c|c|c|c|c|c|c|c|c|c|c|c|c|c|c|}
\hline \multicolumn{2}{|c|}{ Sample } & \multicolumn{2}{|c|}{$S i$} & \multicolumn{2}{|c|}{$C a$} & \multicolumn{2}{|c|}{$M g$} & \multicolumn{2}{|c|}{$A l$} & \multicolumn{2}{|c|}{$S$} & \multicolumn{2}{|c|}{$\mathrm{Fe}$} & \multicolumn{2}{|c|}{$K$} \\
\hline Name & Type & $m w \%$ & s.d. & $m w \%$ & s.d. & $m w \%$ & s.d. & $m w \%$ & s. $d$. & $m w \%$ & s.d. & $m w \%$ & s.d. & $m w \%$ & s.d. \\
\hline w, 5 & Crest & 26.5 & 5.8 & 47.7 & 10.3 & 1.7 & 0.9 & 8.3 & 1.7 & 1.1 & 0.5 & 13.3 & 4.5 & 1.5 & 1.1 \\
\hline $\mathrm{q}, 2$ & Crest & 18.7 & 5.3 & 44.6 & 4.2 & 0.0 & 0.0 & 5.4 & 1.0 & 24.9 & 4.5 & 5.5 & 2.0 & 1.0 & 0.5 \\
\hline $\mathrm{q}, 2$ & Trough & 46.2 & 6.7 & 12.2 & 0.2 & 1.2 & 0.6 & 13.2 & 2.0 & 1.2 & 1.2 & 22.9 & 9.1 & 3.3 & 0.8 \\
\hline $\mathrm{r}, 2$ & Crest & 32.2 & 5.3 & 38.3 & 4.7 & 0.9 & 1.0 & 9.4 & 2.3 & 5.7 & 7.7 & 11.9 & 3.4 & 1.7 & 0.5 \\
\hline $\mathrm{r}, 2$ & Trough & 42.0 & 4.7 & 26.0 & 4.7 & 2.2 & 0.7 & 12.4 & 0.4 & 1.5 & 0.3 & 13.9 & 1.5 & 3.0 & 0.1 \\
\hline $\mathrm{m}, 2$ & Trough & 44.6 & 1.4 & 15.2 & 4.1 & 4.2 & 0.8 & 25.2 & 7.1 & 0.1 & 0.2 & 8.8 & 0.4 & 1.7 & 0.2 \\
\hline $\mathrm{t}, 2$ & Trough & 41.9 & 2.3 & 26.7 & 0.7 & 1.5 & 0.6 & 12.1 & 0.2 & 1.4 & 0.1 & 14.7 & 2.8 & 1.8 & 0.4 \\
\hline s, 6 & Striated & 44.9 & 5.3 & 23.4 & 3.0 & 1.1 & 0.5 & 11.7 & 1.5 & 0.8 & 0.3 & 16.4 & 4.6 & 1.7 & 0.5 \\
\hline s, 6 & Striated & 46.5 & 7.0 & 20.4 & 5.9 & 1.9 & 0.9 & 12.6 & 1.5 & 1.3 & 0.3 & 14.4 & 3.1 & 2.0 & 0.2 \\
\hline
\end{tabular}

Notes: Name column denotes sample name and number of points on sample. Mean weight per cent of cations measured (mw\%) and standard deviation (s.d.) given for overall values of crests and troughs as well as striated samples.

areas it was difficult to distinguish between truncation surfaces and cross-laminae.

\section{Surficial chemical composition}

Bulk chemical analyses (EDS) confirm thin-section observations that both striated and corrugated siltskins are composed of clay- to sand-sized lithic grains cemented by calcite. Siltskin chemistry is a proxy for the relative abundance of lithic fragments in the sample. High $\mathrm{Ca} / \mathrm{Si}$ ratios indicate a low abundance of lithic material. EDS analyses on thin-section stubs, for instance, show that the $\mathrm{Ca} / \mathrm{Si}$ ratios of siltskins display layer-by-layer variation. $\mathrm{Ca} / \mathrm{Si}$ ratios on transects in both " $x$ " (basal layer plane) and " $y$ " (perpendicular to surface) directions range from 2.1 to 8.6 in the calcite-rich layer, and from 1.2 to 2.9 in the microlaminated, lithic-rich upper layer (Fig. 5).

Corrugated and striated siltskins are composed primarily of $\mathrm{Ca}, \mathrm{Si}, \mathrm{Mg}, \mathrm{Al}, \mathrm{S}, \mathrm{Fe}$ and $\mathrm{K}$, but the surface chemistry of corrugated siltskins varies from crests to troughs. Troughs have low $\mathrm{Ca} / \mathrm{Si}$ ratios similar to the bulk chemistry of striated siltskins (Fig. 7). Crests contain about 43\% (mean weight per cent) $\mathrm{Ca}$ and $27 \% \mathrm{Si}$. Troughs and striated samples have $22 \% \mathrm{Ca}$ and $44 \% \mathrm{Si}$. Thus the average crest $\mathrm{Ca} / \mathrm{Si}$ ratio is 1.6 , whereas the trough and the striated skin value is 0.4 (Fig. 7). These values suggest that crests either concentrate or preserve calcite and that the troughs are relatively rich in lithic material. In all crests, troughs and striated samples, $\mathrm{Mg}, \mathrm{S}$ and $\mathrm{K}$ concentrations are $<4 \%$ each, but the Fe concentration is locally as high as $12.5 \%$ (see Table 1). Two crest samples contain measurable S, perhaps from embedded or surficial organic matter.

\section{Ice and water chemistry}

Ice and water samples show that they are calcium- and bicarbonate-rich and of variable ionic strength. Most samples lie near or below the 1:1 correlation line between $\mathrm{Ca}$ and $\mathrm{HCO}_{3}$ (Fig. 8). Measured abundances of $\mathrm{Ca}$ and $\mathrm{HCO}_{3}$ are highest in basal-ice, lower in subglacial-stream and low in "clean"-ice samples. These values indicate that basal ice processes concentrate solutes beneath the lower Mendenhall Glacier. Isotope analyses show that the $\delta \mathrm{O}^{13}$ values in siltskin cement range from $-3.44 \%$ o to $-6.18 \%$ o (PDB), a typical signature for ground- and surface-water carbonates (Wagner, 1998); $\delta \mathrm{O}^{18}$ values range from $-12.74 \%$ to $-19.52 \%$ (PDB), indicating that siltskins precipitated from regelation water films with $\delta \mathrm{O}^{18}$ values of approximately $-40 \%$ (PDB) at $0^{\circ} \mathrm{C}$ (Friedman and O’Neil, 1977). This re- flects the $\delta \mathrm{O}^{18}$ values of the ice from which siltskins precipitated (Hanshaw and Hallet, 1978), though it is expected to be highly variable (Sharp and others, 1995). We did not measure isotopic values on our Mendenhall Glacier samples. However, July $2000 \delta \mathrm{O}^{18}$ values of subglacial meltwater from nearby Herbert Glacier range from $-45.33 \%$ o to $-45.81 \%$ (PDB), and a clean-ice sample had a $\delta \mathrm{O}^{18}$ value of $-44.31 \%$ (PDB). Herbert Glacier drains the Juneau Icefield adjacent to the Mendenhall and has similar area/altitude values.

\section{DISGUSSION}

Siltskin deposition beneath Mendenhall Glacier reflects outcrop to micron-scale interaction of flowing ice, bedrock topography and thin films of water. Our observations suggest that siltskin growth and structure depend on a number of variables: (1) regelation processes on bedrock bumps; (2) concentration of dissolved solutes in thin water films; (3) morphology of the ice-rock interface at local sites on the rock ridge; and (4) formation and operation of a subglacial cavity system. Siltskins thus provide clues about glacier flow over bedrock, and subglacial hydrology. These clues are ephemeral: siltskins exposed to subaerial processes near Mendenhall Glacier, especially to flowing water, disappear within three decades.

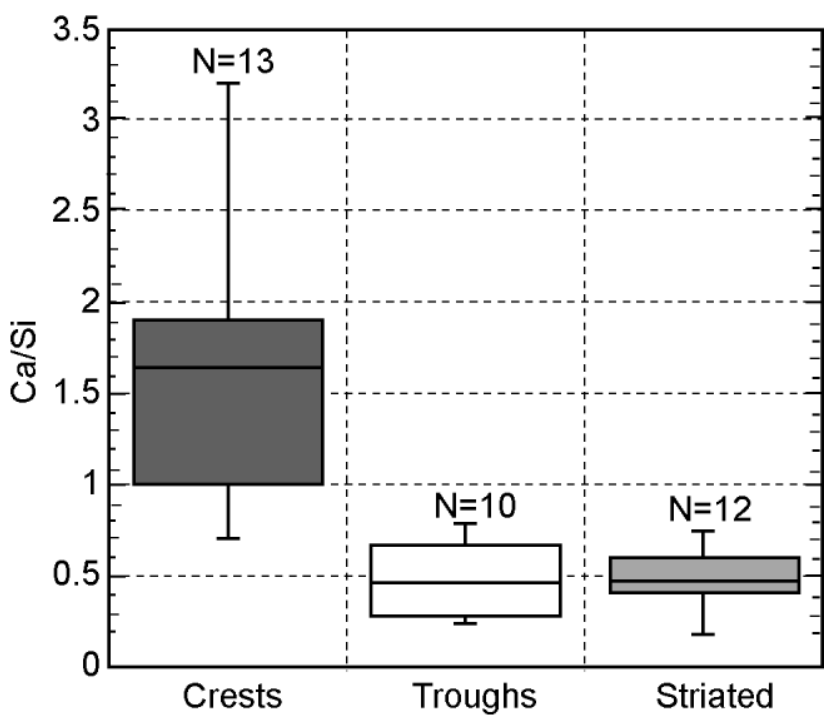

Fig. 7. Box-and-whisker plot showing mean, range and $1 \sigma$ values for Ca/Si ratios in siltskins. Measured by SEM/EDS. 


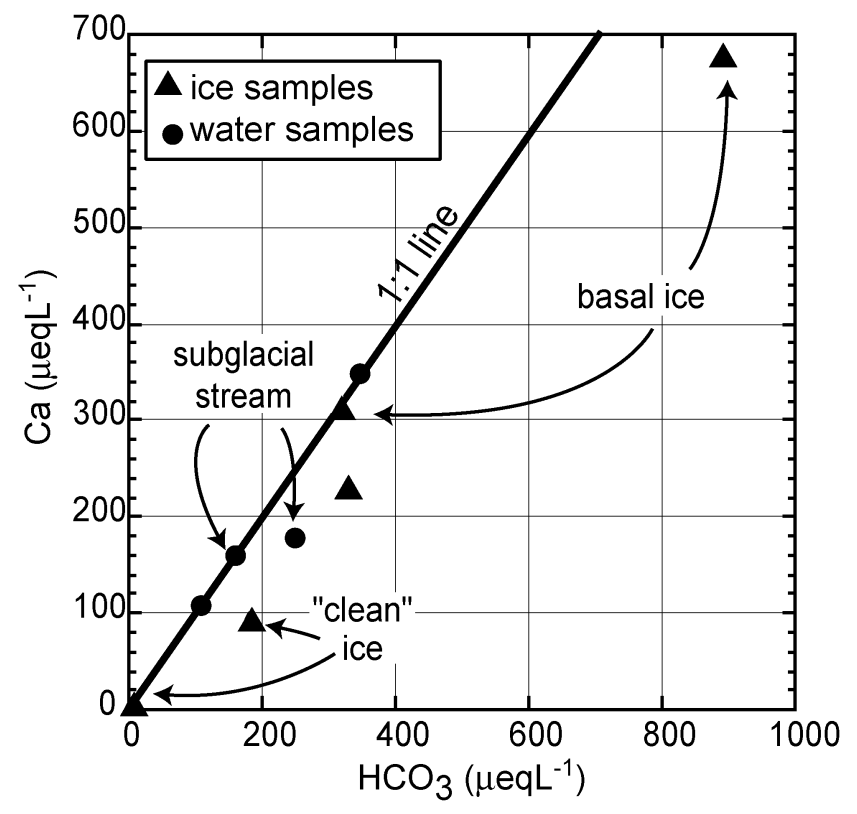

Fig. 8. Plot of $\mathrm{Ca}$ vs $\mathrm{HCO}_{3}$ in ice and water samples collected at Mendenhall Glacier in 2000. Charge balances range from $-9 \%$ to $-23 \%$. ( Several samples were collected and analyzed by $S$. Atkinson.)

\section{Regelation and origin of siltskins}

Field mapping, thin-section analyses, and EDS studies indicate that regelation and related processes deposited calcitecemented siltskins beneath Mendenhall Glacier. Striated siltskins demonstrate that stoss slopes are not only areas of ice melt and mineral dissolution, but also sites for potential solute precipitation. Corrugated siltskins preserve evidence of processes that deposited lithic grains and calcite cement as a series of microlaminated "drips" (corrugations) on top of calcite-rich precipitates.

Siltskin formation on stoss slopes may reflect one of the following processes: (1) formation in a subglacial cavity system when precipitation of solutes was possible on all surfaces; (2) deposition on stoss slopes that are in the lee of bumps that dominate regelation, or (3) solute concentration by evaporation or $\mathrm{CO}_{2}$ loss in air-filled cavities. The presence of siltskins on stoss slopes demonstrates that the location of zones of net freezing on the Mendenhall rock ridge and other hummocky bedrock surfaces (Hubbard and Hubbard, 1998) is hard to predict.

The relatively structureless basal layer of sediment-poor calcite in corrugated siltskins probably records precipitation from a thin film of water onto rock surfaces. Fresh rock surfaces or other geochemical factors may catalyze calcite precipitation in this layer, which then serves as a template for precipitation of the microlaminated layers. These overlying layers record episodes of flow and deposition from a fluid saturated by $\mathrm{CaCO}_{3}$. Alternation of dark (finer-grained) and light (coarser-grained) laminae, and EDS analyses suggest cyclical changes in the subglacial environment, and episodic entrainment of minor amounts of relatively coarse material. Grains are mainly clay- and silt-sized and rich in silica. Likely controls on grain-size are the low flow velocity of the depositing fluid and narrow ice-rock separation. Basal ice presently exposed at Mendenhall Glacier locally is sediment-rich and contains grains of all sizes, so coarse material is available. If ice/rock separation is widespread at the time of siltskin formation, this material may be transportable to areas of precipitation and available for deposition in siltskins.

\section{Origin of calcite in siltskins}

Calcite layers and cement in siltskins form by precipitation from fluids enriched in dissolved solutes by subglacial process of concentration. Siltskin layering (Figs 5 and 6) suggests that calcite initially precipitates on rock faces and then is covered by sediment-rich, calcite-saturated solutions. Basal-layer calcite and cement in the upper layer likely form from concentration of Ca released by weathering of feldspar (Brown and others, 1996) and lenses of calcite upstream in the catchment. Concentrations of $\mathrm{Ca}$ and $\mathrm{HCO}_{3}$ increase from the englacial to subglacial hydrologic environments at Mendenhall Glacier (Fig. 8). Basal ice and water at the Mendenhall may be enriched in Ca because of continued rejection of solutes from growing ice and their concentration in subglacial water (Hallet and others, 1978). Concentration of solutes in basal ice also may record local freezing on of supercooled water (Evenson and others, 2002), though we did not recognize layering in basal ice that often is associated with these processes. Basal ice we sampled at Mendenhall Glacier has a saturation index of about -1.4 (Hem, 1989), approximately $5 \%$ of the saturation value with calcite at $0^{\circ} \mathrm{C}$. If regelation-induced concentration of solutes in laboratory settings provides a good model for the field (Hallet, 1976a, b), concentration of solutes from the basal ice by regelation processes would produce solutions supersaturated with calcite. However, if the geometry of the meltwater space is irregular, precipitation of solutes will occur more easily (Killawee and others, 1998).

\section{Possible controls on microlaminae deposition and erosion}

The shape and downslope elongation of corrugated siltskins suggests that they formed in cavities that were not filled with water during or after siltskin deposition and likely reflect nearby ice--bedrock interaction. For instance, the icebedrock separation decimeters to meters up-ice may influence the internal structures that develop in corrugated siltskins. Where ice is separated from the bedrock by an extremely thin (microns thick) regelation layer and nearby cavities are unsaturated, little water is able to flow down the rock face. Where the ice and rock are separated by larger gaps (10 $\mu$ m or more), water and sediment both are available to flow down adjacent rock surfaces. If rock-ice separation is intermediate, water and sediment may drip slowly down the rock face.

Differences in grain-size between microlaminae may reflect control by the velocity of and size distribution of lithic fragments in the water film. Alternating layers suggest cyclical changes in subglacial hydrology or sediment availability. Cycles could reflect daily changes, seasonal variation, changes in subglacial water flow directions, or a combination of these factors.

Thin-section evidence shows that siltskins evolve by complex repetition of events such as episodes of deposition and erosion within growing coatings. Such processes truncate microlaminae, and may help control the wavelength of corrugations and shape of crests (Fig. 3). However, because subglacial precipitation is not likely where water flow exceeds that derived from regelation (Hallet, 1979; 
a

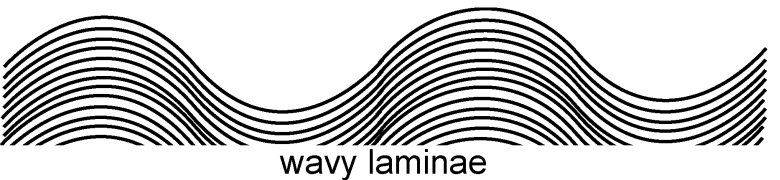

b
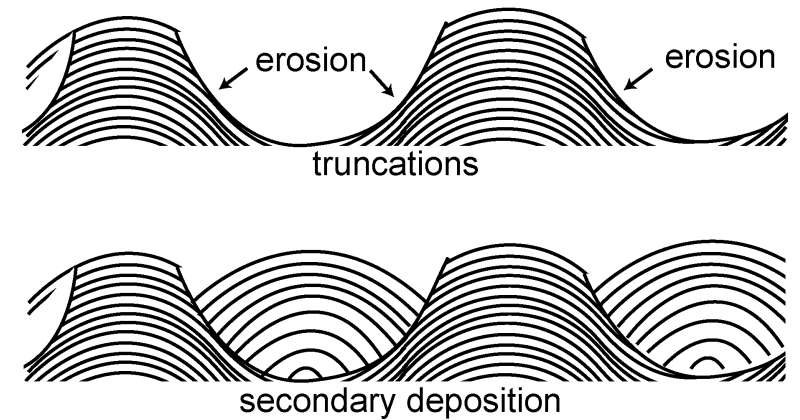

d

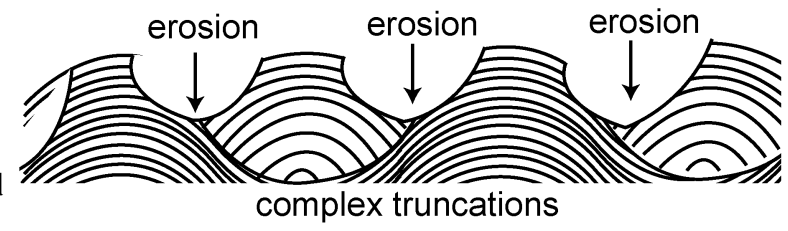

Fig. 9. Sketch showing how originally wavy laminations might appear as truncations after two phases of deposition and erosion. (a) Initially wavy laminations. (b) After erosion, laminations may appear truncated. (c) Secondary deposition. (d) Secondary erosion allows the appearance of complex truncations and may be a control on crest type and wavelength.

Sharp and others, 1990), corrugated siltskins cannot form or persist where cavities are filled with water. The preferred deposition of siltskins on lee slopes may be due, in part, to solute redistribution. Hallet and others (1978) suggest that solute concentrations on lee slopes or areas of freezing are 50-100 times higher than stoss (melting) slope concentrations.

Post-depositional water flow over siltskins may produce or enhance corrugation and cause changes in siltskin surface chemistry. The internal structure of corrugated siltskins records alternating depositional and erosional environments. Erosion begins when thin-film depositional processes are no longer active, allowing siltskins to erode from water dripping or flowing over their surface. Where a film of water moves down a siltskin surface, it may preferentially dissolve calcite cement in the siltskin troughs. Preferential dissolution in siltskin troughs exposes lithic grains and may account for the surficial chemical differences between crests and troughs.

Although puzzling, preservation of orderly appearing corrugations with internally complex and convoluted structures records regelation-induced precipitation of a calcite layer followed by alternating episodes of deposition and erosion of silt-rich layers. Changes in processes recorded by the microlaminated layer may reflect evolution in the rate of heat transfer involved in regelation, or variations in the flux of meltwater relative to the freezing rate and extent of separation. Where regelation slows, or where there is an increase in meltwater or glacier-bed separation, water from the basal ice layer may still drip down lee faces. The tendency of water to form drips at even intervals may allow for initial deposition of wavy laminae (Fig. 9a) ( $\mathrm{Ng}$ and
Hallet, 2002). We assume that calcite cementation of lithic grains continues as these drips form on siltskins. If an interval of wavy-laminae accretion is followed by erosion of existing structures, preferential water flow and dissolution in corrugation troughs may truncate microlaminae (Fig. 9b). Repetition of such accretion-erosion cycles, combined with the effects of soft sediment deformation (see Fig. 6c), may result in the complex internal structures observed in many siltskins, and allow for regular spacing of corrugations (Fig. $9 \mathrm{c}$ and d). However, specific processes that produce both internal structures and corrugations are only vaguely evident.

\section{Siltskins as evidence for glacier sliding at Menden- hall Glacier}

Siltskins at Mendenhall Glacier provide evidence for the interaction of flowing ice, bedrock and thin films of water in the subglacial environment. Striated siltskins found on stoss faces demonstrate contemporaneous ice sliding and deposition of calcite coatings, whereas the microstructures and laminae of corrugated siltskins imply deposition in adjacent cavities at atmospheric pressure. The relative abundance of siltskins on the bedrock ridge adjacent to Mendenhall Glacier suggests that siltskins formed and were preserved in the vicinity of a subglacial cavity system that developed beneath thinning ice (Fig. 1b). Local ice-flow directions recorded by two distinct striation directions in the striated siltskins and on the rock ridge show that the siltskins formed both during the Little Ice Age (LIA) maximum (Miller, 1975) and during the past 60 years. During the LIA maximum, Mendenhall Glacier was thicker and the rock ridge did not affect ice-flow direction. As the ice thinned, the glacier was deflected southeast by the rock ridge. Preservation of siltskins requires that water flow in the cavities must have been minimal to moderate. Siltskins preserve ephemeral evidence of processes active in a realm that is otherwise difficult to study, and demonstrate that regelation and related processes are sufficient to produce precipitation of calcite cement in areas of carbonate-poor bedrock. The structure and composition of siltskins suggest that the relative importance of subglacial processes, including meltwater flow, glacier-bed separation, comminution and dissolution of bedrock and chemical precipitation under Mendenhall Glacier, are different from those under glaciers sliding over carbonate bedrock where subglacial carbonate deposits have been examined in previous studies.

\section{ACKNOWLEDGEMENTS}

The Keck Geology Consortium and Williams College helped to fund this research. We wish to thank R. Carson, P. J. Fleischer and the Alaska Keck 2000 students for assistance in the field; N. Piatczyc, S. Brown and J. Caris, for laboratory guidance; and S. Atkinson for use of his data. We also thank scientific editors N. Glasser and T. Scambos. B. Hallet and J. Dixon provided extremely helpful and insightful comments as reviewers.

\section{REFERENGES}

Brown, G. H., M. Sharp and M. Tranter. 1996. Subglacial chemical erosion: seasonal variations in solute provenance, Haut Glacier d'Arolla, Valais, Switzerland. Ann. Glaciol., 22, 25-31.

Dixon, J. C., C. E. Thorn, R. G. Darmody and S. W. Campbell. 2002. Weath- 
ering rinds and rock coatings from an Arctic alpine environment, northern Scandinavia. Geol. Soc. Am. Bull., 114(2), 226-238.

Evenson, E. B., D. E. Thorn, R. G. Darmody and S.W. Campbell. 2002. Weathering rinds and rock coatings from an Arctic alpine environment, northern Scandinavia. Geol. Soc. Am. Bull., 114(2), 226-238

Ford, D. C., P. G. Fuller and J. J. Drake. 1970. Calcite precipitates at the soles of temperate glaciers. Nature, 226(5244), 441-442.

Friedman, I. and J. R. O'Neil. 1977. Compilation of stable isotope fracturation factors of geochemical interest. U.S. Geol. Surv. Prof. Pap. 440KK, Data Geochemistry, Sixth edition.

Hallet, B. 1975. Subglacial silica deposits. Nature, 254(5502), 682-683.

Hallet, B. 1976a. Deposits formed by subglacial precipitation of $\mathrm{CaCO}_{3}$.> Geol. Soc. Am. Bull., 87(7), 1003-1015.

Hallet, B. 1976b. The effect of subglacial chemical processes on glacier sliding. 7. Glaciol., 17(76), 209-221.

Hallet, B. 1979. Subglacial regelation water film. 7. Glaciol., 23 (89), 321-334.

Hallet, B. and R.S. Anderson. 1981. Detailed glacial geomorphology of a proglacial bedrock area at Castleguard Glacier, Alberta, Canada. Z Gletscherkd. Glazialgeol., 16(2), [1980], 171-184.

Hallet, B., R. Lorrain and R. Souchez. 1978. The composition of basal ice from a glacier sliding over limestones. Geol. Soc. Am. Bull., 89(2), 314-320.

Hanshaw, B. B. and B. Hallet. 1978. Oxygen isotope composition of subglacially precipitated calcite: possible paleoclimatic implications. Science, 200(4347), 1267-1270.

Hem, J. D. 1989. Study and interpretation of the chemical characteristics of natural water. Washington DC, U.S. Government Printing Office.

Hubbard, B. and A. Hubbard. 1998. Bedrock surface roughness and the distribution of subglacially precipitated carbonate deposits: implications for formation at Glacier de Tsanfleuron, Switzerland. Earth Surf. Processes Landforms, 23(3), 261-270.

Killawee, J. A., I. J. Fairchild, J.-L. Tison, L. Janssens and R. Lorrain. 1998. Segregation of solutes and gases in experimental freezing of dilute solutions: implications for natural glacial systems. Geochim. Cosmochim. Acta, 62(23-24), 3637-3655.

Menzies, J. 1995. Hydrology of glaciers. In Menzies, J., ed. Modern glacial environments: processes, dynamics and sediments. Vol. 1. Glacial environments. Oxford, etc., Butterworth-Heinemann, 197-239.

Miller, R. D. 1975. Surficial geologic map of the funeau urban area and vicinity, Alaska. (Scale 1:48,000.) Reston, VA, U.S. Geological Survey. (Misc. Investigation Series Map I-885.)

Ng, F. and B. Hallet. 2002. Patterning mechanisms in subglacial carbonate dissolution and deposition. 7. Glaciol., 48 (162), 386-400.

Paterson, W. S. B. 1994. The physics of glaciers. Third edition. Oxford, etc., Elsevier.

Sharp, M., G. H. Brown, M. Tranter, I. C. Willis and B. Hubbard. 1995. Comments on the use of chemically based mixing models in glacier hydrology. 7. Glaciol., 41 (138), 241-246.

Sharp, M. J., J.-L. Tison and G. Fierens. 1990. Geochemistry of subglacial calcites: implications for the hydrology of the basal water film. Arct. Alp. Res., $22(2), 141-152$.

Wagner, G. 1998. Age determination of young rocks and artifacts. New York, Springer.

Wahrhaftig, C. 1992. Maps of the physiographic divisions of Alaska. (Scale 1:250,000.) Boulder, CO, Geological Society of America. (Geology of Alaska (Plates) G-1.)

Weertman, J. 1957. On the sliding of glaciers. F. Glaciol., 3(21), 33-38.

MS received 31 January 2003 and accepted in revised form 17 December 2003 